\title{
Cyclodextrin-PEI-Tat Polymer as a Vector for Plasmid DNA Delivery to Placenta Mesenchymal Stem Cells
}

\author{
Wing-Fu Lai • Gu-Ping Tang • Xin Wang • Guo Li • \\ Hong Yao • Zan Shen • Gang Lu • Wai Sang Poon • \\ Hsiang-Fu Kung • Marie C. M. Lin
}

Published online: 18 June 2011

(C) The Author(s) 2011. This article is published with open access at Springerlink.com

\begin{abstract}
This study aims to modify a cyclodextrin-PEIbased polymer, PEI- $\beta-\mathrm{CyD}$, with the TAT peptide for plasmid DNA delivery to placenta mesenchymal stem cells (PMSCs). By using the disulfide exchange between the SPDP-activated PEI- $\beta$-CyD and TAT peptide, the TAT-PEI$\beta$-CyD polymer was fabricated and the success of this was confirmed by the presence of characteristic peaks for PEI (at $\delta$ 2.8-3.2 ppm), CyD (at $\delta 5.2,3.8-4.0$ and 3.4$3.6 \mathrm{ppm}$ ) and TAT (at $\delta 1.6-1.9$ and 6.8-7.2 ppm) in the ${ }^{1} \mathrm{H}$ NMR spectrum of TAT-PEI- $\beta$-CyD. The polymer-plasmidDNA polyplex could condense DNA at an N/P ratio of 7.08.0 , and form nanoparticles with the size of $150.6 \pm 5.6 \mathrm{~nm}$ at its optimal N/P ratio (20/1). By examining the transfec-
\end{abstract}

Wing-Fu Lai, Gu-Ping Tang, and Xin Wang contributed equally to this article.

Electronic supplementary material The online version of this article (doi:10.1007/s12668-011-0010-9) contains supplementary material, which is available to authorized users.

H. Yao $\cdot$ G. Lu $\cdot$ W. S. Poon • M. C. M. Lin $(\bowtie)$

Brain Tumor Centre and Division of Neurosurgery, Department of

Surgery, The Chinese University of Hong Kong,

Hong Kong SAR, China

e-mail: mcllin@hkusua.hku.hk

W.-F. Lai $\cdot$ G.-P. Tang $\cdot$ H. Yao $\cdot$ Z. Shen $\cdot$ M. C. M. Lin

Department of Chemistry, The University of Hong Kong,

Hong Kong SAR, China

X. Wang $\cdot$ G. Li $\cdot$ H.-F. Kung $(\bowtie)$

State Key Laboratory of Oncology in Southern China and Stanley

Ho Center for Emerging Infectious Diseases,

The Chinese University of Hong Kong,

Hong Kong SAR, China

e-mail: b110473@mailserv.cuhk.edu.hk tion efficiency and cytotoxicity of TAT-PEI- $\beta-\mathrm{CyD}$, conjugation of the TAT peptide onto PEI- $\beta-C y D$ was demonstrated to improve the transfection efficiency of PEI- $\beta$-CyD in PMSCs after 48 and 96 hours of posttransfection incubation. The viability of PEI- $\beta$-CyD-treated PMSCs was shown to be over $80 \%$ after $5 \mathrm{~h}$ of treatment and $24 \mathrm{~h}$ of post-treatment incubation. In summary, this study showed that the TAT-PEI- $\beta$-CyD polymer as a vector for plasmid DNA delivery to PMSCs and other cells warrants further investigations.

Keywords $\beta$-cyclodextrin - Nucleic acid delivery $\cdot$ Placenta mesenchymal stem cells $\cdot$ Poly (ethylenimine) $\cdot$ Tat peptide

Z. Shen

Department of Oncology, Affiliated 6th People's Hospital,

Shanghai Jiao Tong University,

Shanghai, China

G.-P. Tang

Institute of Chemical Biology and Pharmaceutical Chemistry,

Zhejiang University,

Hangzhou, People's Republic of China 


\section{Introduction}

Stem cells have a unique capacity to differentiate into different cell types. This renders them an unlimited source of practical prospects in regenerative medicine [1-3]. Owing to their utility in numerous biomedical applications [4-7], over the years stem cells have been attracting scientific interests. Recently, the concept of nucleic acid (NA) therapy targeting stem cells emerged, and will potentially open a new window to medical frontiers owing to its plausibility of tackling diseases such as Parkinson's disease, diabetes mellitus, and cancers $[8,9]$.

Thus far copious approaches have been studied for transferring therapeutic transgenes into stem cells. As far as correction of a genetic pathology is concerned, the stem cells are usually meant to express therapeutic genes for the duration of a patient life. For such purposes, it is best to use integrating viruses (such as retroviruses and lentiviruses) [10-12]. Alternatively, if short-term transgene expression in stem cells is required, non-integrating vectors such as adenoviruses or herpes simplex viruses will become more preferable. Though viral vectors successfully deliver NA into stem cells $[8,9]$, their immunogenicity and other critical safety concerns limit their clinical applications [13, 14]. For this, extensive research efforts have been diverted into the search of non-viral methods (such as electroporation and liposomes). The latest development of nonviral NA delivery systems has recently been reviewed by Mintzer and Simanek [15]. Despite their potential in NA transfer, the in vivo and clinical uses of non-viral carriers have been greatly hampered by their low transfection efficiency and cytotoxicity [13, 14, 16-18].

Compared to other polymeric methods being explored, cyclodextrin-based polymers attract much attention [19]. This is due to their biocompatibility, low toxicity, and nonimmunogenicity. Gonzalez et al. was the first team to report the potential use of $\beta$-cyclodextrin $(\beta-\mathrm{CyD})$-containing polymers for NA delivery [20]. Since then numerous CyDbased NA vectors have been developed [21-23]. For details, please refer to reviews in the published literature [19, 24]. Currently, one of the CyD-based vectors, CALAA-01, successfully proceeds to clinical trials and provides targeted delivery of synthetic small interfering RNA (siRNA) [21]. In view of the promise of cyclodextrin-based NA delivery systems, a $\beta$-CyD-based polymer conjugated with low molecular weight PEI (PEI- $\beta$-CyD) has previously been described with reasonable transfection efficiency and low toxicity [25]. Here, we incorporate a cell-penetrating peptide containing the protein transduction domain (PTD) of the HIV-1 TAT protein to form a TAT-PEI- $\beta$-CyD polymer. As the TAT peptide was experimentally shown to promote the rapid cellular uptake of multiple chemical entities [26, 27], it was expected that conjugation of TAT to PEI- $\beta-\mathrm{CyD}$ would produce a polymer that promotes the efficacy of NA delivery into various cells. It is anticipated that conjugating the PTD of the HIV-1 TAT peptide with the PEI- $\beta$-CyD polymer could potentially develop a non-cytotoxic yet effective NA delivery vehicle for meeting the needs brought about by the emergence of stem cell technology.

\section{Materials and Methods}

\subsection{Materials}

PEI $(\mathrm{Mw}=25 \mathrm{kDa}$ and $0.8 \mathrm{kDa}), \beta$-cyclodextrin, 1,1'carbodiimidazole (CDI), dimethyl sulfoxide (DMSO), $\beta$ cyclodextrin and 3-(4,5-dimethylthiazol-2-yl)-2,5-diphenyltetrazolium bromide (MTT) were purchased from SigmaAldrich (St. Louis, MO, USA). N-succinimidyl 3-(2pyridyldithio)propionate (SPDP) was purchased from Pierce (USA). 13-amino acid peptide YGRKKRRQRRRPC derived from TAT was specially ordered from Guangzhou Jetway Biotech Co. Ltd (China). All reagents were used as received unless otherwise specified.

\subsection{Polymer Synthesis and Characterization}

Synthesis of PEI- $\beta$-CyD was carried out based on the methods developed by Tang et al. [25]. The synthesis of PEI- $\beta$-CyDTAT was carried out by first allowing SPDP ( $3 \mathrm{mg}$, in $1.5 \mathrm{ml}$ DMSO $)$ and PEI- $\beta$-CyD (120 mg, in $5.0 \mathrm{ml}$ DMSO $)$ to react at room temperature for $1 \mathrm{~h}$ under nitrogen with constant stirring. Peptide (21 mg, in $1.5 \mathrm{ml}$ DMSO) was allowed to react with SPDP-activated PEI- $\beta-C y D$ for $3 \mathrm{~h}$. After the reaction, the reaction mixture was dialyzed with dialysis tubing (molecular weight cut-off $=12 \mathrm{kDa}$ ) against doubly deionized water for 2 days and freeze dried for another 2 days.

After polymer synthesis, samples of the agent to be tested (i.e., TAT, PEI- $\beta$-CyD or TAT-PEI- $\beta-C y D ; 1 \mathrm{mg}$ ) were dissolved in $0.5 \mathrm{ml}$ of $\mathrm{D}_{2} \mathrm{O}$ (Cambridge Isotope Laboratories, Inc., MA, USA) at room temperature. The ${ }^{1} \mathrm{H}$ NMR spectrum of TAT, PEI- $\beta-C y D$ and TAT-PEI- $\beta-C y D$ were studied by Bruker Avance 300 spectrometer $(300 \mathrm{MHz})$. Further, TAT, PEI- $\beta$-CyD and TAT-PEI- $\beta$-CyD were studied by UV/Vis spectrometer (Lambda Bio 40). In brief, the sample to be tested was dissolved in $1 \mathrm{ml}$ of doubly deionized water and scanned by UV-Visible spectrometer from $200 \mathrm{~nm}$ to $400 \mathrm{~nm}$. Cary 300 software (Varian, Palo Alto) was employed to analyze the signals.

\subsection{Polyplex Formation, Characterization and pDNA Binding Studies}

TAT-PEI- $\beta$-CyD/pDNA polyplexes were prepared as reported by Lai and Lin [28]. In brief, the polymer solution 
(in distilled water) and DNA plasmid solution (in Tris/ EDTA buffer) were mixed in equivalent volume and at appropriate $\mathrm{N} / \mathrm{P}$ ratios. The mixture was vortexed and then stayed at ambient conditions for $30 \mathrm{~min}$ before use. The size of the TAT-PEI- $\beta$-CyD/pDNA polyplex was characterized by transmission electron microscopy (TEM; Philips CM300, Holland) with electron kinetic energy of $300 \mathrm{keV}$. One drop of the freshly prepared complex solution was placed onto a copper grid coated with carbon field and was air-dried at room temperature. Further, the surface charge of polyplexes was determined by a ZetaPALS zeta potential analyzer (Brookhaven). Each measurement of particle size zeta potential and was repeated ten times, and an average value was reported.

Ethidium bromide displacement assay was performed to study the pDNA condensing abilities of TAT-PEI- $\beta$-CyD. It was done in which ethidium bromide (153 $\mu$ l of a $0.01 \%$ solution) was added to $96 \mu \mathrm{g}$ of EGFP plasmids and diluted to $6 \mathrm{ml}$. Desired concentrations of TAT-PEI- $\beta-\mathrm{CyD}$ solutions were added to each well of a 96-well-microplate respectively; $50 \mu \mathrm{l}$ of the DNA-ethidium bromide solution was added to obtain a final volume of $100 \mu$ l. After a 5-min incubation, the complexes were treated with $100 \mu \mathrm{l}$ of distilled water. The fluorescence was measured by SPECTRAFluor Plus, TECAN. Additionally, the pDNA condensing abilities of TAT-PEI- $\beta$-CyD was verified by using gel retardation assay, during which $\mathrm{N} / \mathrm{P}$ ratios of 5:1, 10:1, 20:1, 30:1, 40:1, and 50:1 were first prepared. Loading buffer was then added after polyplexes formation. It was loaded into a $1 \%$ agarose gel with ethidium bromide and run in TAE buffer at $80 \mathrm{~V}, 60 \mathrm{~min}$ at room temperature. DNA bands were visualized by a UV illuminator.

\subsection{In Vitro Transfection Assay}

PMSCs were harvested from three placentas (gestational ages, 38-40 weeks) which were obtained from the Prince of Wales Hospital in Hong Kong according to previously established protocols [29, 30]. Tissue collections for research were approved by the Joint Clinical Research Ethics Committee of The Chinese University of Hong Kong and New Territories East Cluster. The isolation of PMSCs was in reference to the protocol reported by Chen et al. [31]. In brief, $100 \mathrm{~g}$ of tissue collected from the central placental cotyledons was cut into 1-2 $\mathrm{mm}$ fragments, trypsinized $(0.25 \%$ trypsin-EDTA solution; Invitrogen, Carlsbad, CA, USA) and treated thrice with $10 \mathrm{U} / \mathrm{ml}$ DNAse I (Sigma, St Louis, MO, USA) in Dulbecco's modified Eagle's medium (DMEM; GIBCO, Grand Island, NY, USA) at $37^{\circ} \mathrm{C}$ for $5 \mathrm{~min}$. Afterwards, the mixture was filtered through a $70-\mathrm{mm}$ cell strainer (BD Biosciences, San Jose, CA, USA), with the supernatants being pooled and spun at $1,000 \times g$ for $10 \mathrm{~min}$. With the use of Percoll density gradient fractionation $(1.073 \mathrm{~g} / \mathrm{ml}$, Sigma), mononuclear cells in the medium were recovered, and then were resuspended and seeded in a $25 \mathrm{~cm}^{2}$ flask [32]. Cultures were maintained in DMEM (supplemented with $10 \% \mathrm{FBS}$ ) at $37^{\circ} \mathrm{C}$ with $5 \% \mathrm{CO}_{2}$, and medium changes were performed every 3 days. After around $2-$ 3 weeks when colonies consisting of fibroblast-like cells were observed, cells from those colonies were trypsinized and replated for expansion under $5 \% \mathrm{CO}_{2}$ at $37^{\circ} \mathrm{C}$. In order to attain single-cell-derived, clonally expanded MSCs, second-passage cells were serially diluted and plated in 96-well plates (Costar) at a final density of 60 cells/plate. After 1-2 weeks, colonies that exhibited homogeneous bipolar morphology were isolated, cultured, and expanded.

PMSCs were seeded into a 24-well plate at a density of $2 \times 10^{4}$ per well with $0.5 \mathrm{ml}$ of P-GM $24 \mathrm{~h}$ prior to transfection. At the time of transfection, the medium in each well was replaced with $200 \mu$ l of serum free DF12 medium containing TAT-PEI- $\beta-\mathrm{CyD} / \mathrm{pEGFP}$ complexes. After incubating for $4 \mathrm{~h}$ at $37^{\circ} \mathrm{C}$, the medium was replaced with $0.5 \mathrm{ml}$ of fresh complete DF12 medium. The transfection of FuGENE 6 was carried out according to the protocol stated. The transfection efficiency of the polymer and FuGENE 6 on PMSCs was assayed by confocal microscopy 24, 48 and $96 \mathrm{~h}$ after transfection. The cells in three random fields with the same magnification were counted for EGFP expression.

The U87, U138, Cho, HepG2, and 293T cells were maintained and transfected by the standard protocol as described previously [31]. Briefly, $2 \times 10^{4}$ cells/well were seeded on 24-well plates and allowed to incubate for approximately $16 \mathrm{~h}$ in serum containing medium. At the time of transfection, polyplexes were formed with $2 \mu \mathrm{g}$ of pEGFP and a desired amount of TAT-PEI- $\beta$-CyD, and were added into the cells for a 4.5-h incubation. The transfecting medium was then replaced by fresh medium. Transfection efficiency was assayed by confocal microscopy $48 \mathrm{~h}$ after transfection. The cells in three random fields with the same magnification were counted for EGFP expression.

Before and after transfection, phenotypic marker identification was performed by flow cytometry on PMSCs. The protocol adopted was in reference to the one reported earlier by [33]. In brief, $10^{5}$ cells were resuspended in $100 \mu \mathrm{l}$ of $\mathrm{PBS}$ and incubated with primary antibodies (anti-human CD34, CD38, CD45, CD90, CD147 and HLA-DR) at $4{ }^{\circ} \mathrm{C}$ for $1 \mathrm{~h}$ with $1: 100$ dilutions. The labeled cells were suspended in $100 \mu \mathrm{l}$ of PBS, and incubated with $1 \mu$ goat anti-mouse IgG conjugated with FITC (Chemicon, AP124F) at $4^{\circ} \mathrm{C}$ for $1 \mathrm{~h}$. Afterwards, they were examined with a FACSCalibur apparatus (Becton-Dickinson). 


\subsection{MTT Assay}

Desired amounts of polymers and EGFP plasmids were mixed with the serum free medium to $200 \mu$ l to make the polyplex solutions. PMSCs were seeded onto 96-well plates at a density of $1 \times 10^{4}$ cells per well in $200 \mu \mathrm{l}$ of growth medium, incubated for $18 \mathrm{~h}$ to reach $75-80 \%$ confluence. The medium was replaced with $200 \mu$ of a polyplex solution. After $5 \mathrm{~h}$ of incubation, the polyplex solution was removed. MTT assay was performed after $24 \mathrm{~h}$ by a standard protocol as described by the manufacturer. The percentage of cell viability was calculated using the equation $\left([A]_{\text {test }} /[A]_{\text {control }}\right) \times 100 \%$.

\section{Results}

\subsection{Synthesis and Characterization of TAT-PEI- $\beta-\mathrm{CyD}$}

The polymer's synthetic pathways as well as the schematic representation of its polyplex formation process were illustrated in Fig. 1. The primary amine groups of PEI in PEI- $\beta$-CyD was activated by SPDP in DMSO, followed by their disulfide exchange with the TAT peptide, giving the product TAT-PEI- $\beta$-CyD.

The success of the conjugation process between TAT and the PEI- $\beta$-CyD backbone was confirmed by the chemical shifts of PEI $\left(2.8-3.2 \mathrm{ppm}:-\mathrm{CH}_{2} \mathrm{CH}_{2} \mathrm{~N}-\right), \beta-\mathrm{CyD}\left(\mathrm{H}_{1}\right.$, $5.2 \mathrm{ppm} ; \mathrm{H}_{3}, \mathrm{H}_{5}$ and $\mathrm{H}_{6}, 3.8-4.0 \mathrm{ppm}, \mathrm{H}_{2}$ and $\mathrm{H}_{4}, 3.4-$ $3.6 \mathrm{ppm})$ and TAT $\left(-\mathrm{CH}_{2}-, 1.6-1.9 \mathrm{ppm}\right.$, aromatic protons from TAT, 6.8-7.2 ppm) in the NMR spectrum of the product (Supplementary Data 1). Further, the mole ratio between PEI and $\beta$-CyD of PEI- $\beta$-CyD was calculated from the characteristic peaks of PEI $\left(-\mathrm{CH}_{2} \mathrm{CH}_{2} \mathrm{NH}-\right.$; at $\delta$ 2.3-2.8 ppm) and $\mathrm{C}-1$ hydrogen in $\beta$-CyD. It was approximated to be 1:1.1. In UV-Visible light spectrometry, PEI- $\beta$-CyD did not show any absorption around $285 \mathrm{~nm}$, while both TAT and TAT-PEI- $\beta$-CyD showed large absorption peaks at $285 \mathrm{~nm}$ (Fig. 2a).

\subsection{Polyplex Formation and Characterization}

The particle sizes of TAT-PEI- $\beta$-CyD/DNA polyplexes were estimated by TEM, and found to be larger than that of PEI$\beta-\mathrm{CyD} / \mathrm{DNA}$ polyplex at the range of N/P ratios examined (from $5 / 1$ to $50 / 1$ ). The size of the TAT-PEI- $\beta$-CyD polyplex $(\mathrm{N} / \mathrm{P}$ ratio $=20)$ was estimated to be of $150.6 \pm 5.6 \mathrm{~nm}$ (Fig. 2b), with relatively narrow and unimodal size distributions ranging from 150 to $200 \mathrm{~nm}$.

The zeta potentials of TAT-PEI- $\beta$-CyD/DNA polyplexes at different $\mathrm{N} / \mathrm{P}$ ratios were found to be lower than that of PEI- $\beta$-CyD polyplexes (Fig. $2 \mathrm{c}$ ). In addition, the zeta potentials of TAT-PEI- $\beta$-CyD/DNA polyplexes were posi-

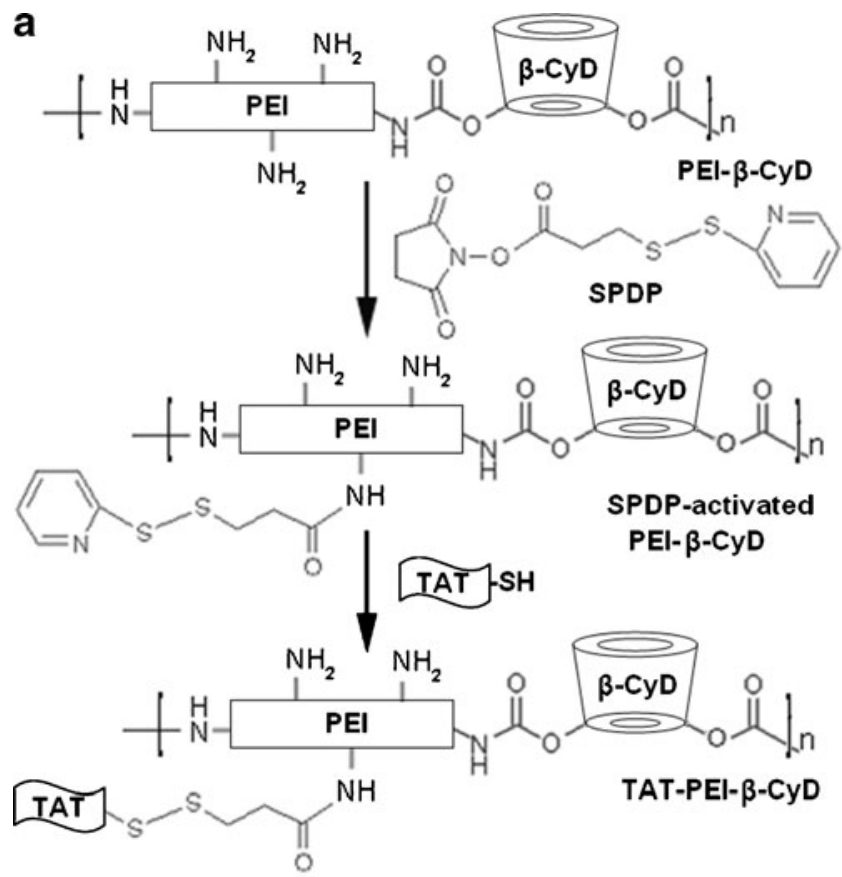

b

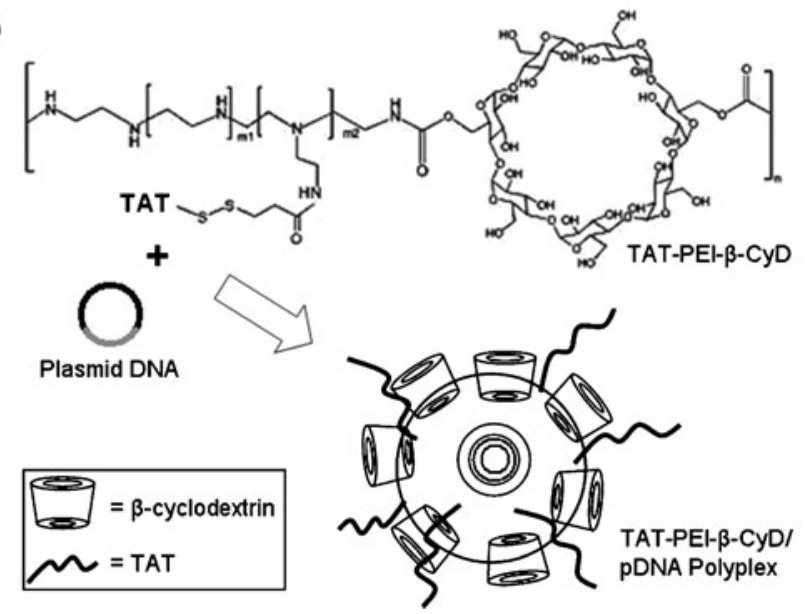

Fig. 1 a Reaction scheme of the synthesis of TAT-PEI- $\beta$-CyD. b Schematic representation of the structure of TAT-PEI- $\beta-C y D$ and the polyplex formation by TAT-PEI- $\beta-\mathrm{CyD}$ and plasmid DNA

tive at all $\mathrm{N} / \mathrm{P}$ ratios tested, with the value being higher than $+20 \mathrm{mV}$ at the N/P ratios over $20 / 1$.

Having high DNA condensing ability is an important factor for a successful polymeric gene delivery system. By the ethidium bromide displacement assay, TAT-PEI- $\beta$-CyD was shown to completely retard DNA at N/P ratios 7.0-8.0 (Fig. 2d), and had similar DNA condensation ability to PEI$\beta-\mathrm{CyD}$ as demonstrated by gel retardation (Supplementary Data 1).

\subsection{Transfection and Cytotoxicity}

As shown in Fig. 3, the transfection efficiency of TAT-PEI$\beta-\mathrm{CyD}(\mathrm{N} / \mathrm{P}$ ratio $=20,48$-h post-transfection incubation) in 
Fig. 2 a UV spectrum of TATPEI- $\beta$-CyD, PEI- $\beta$-CyD, and TAT peptide. The increase in absorption at $285 \mathrm{~nm}$ indicates the successful conjugation of TAT peptide to PEI-CyD; $\mathbf{b}$ Electron micrograph of TAT-PEI$\beta-\mathrm{CyD} / \mathrm{pEGFP}$ complexes. White bar is $200 \mathrm{~nm}$. c Zeta potential of TAT-PEI- $\beta$-CyD/ pEGFP polyplexes at different $\mathrm{N} / \mathrm{P}$ ratios. $\mathbf{d}$ Ethidium bromide displacement assay of PEI- $\beta$ $\mathrm{CyD} / \mathrm{pEGFP}$ compared with TAT-PEI- $\beta$-CyD/pEGFP a

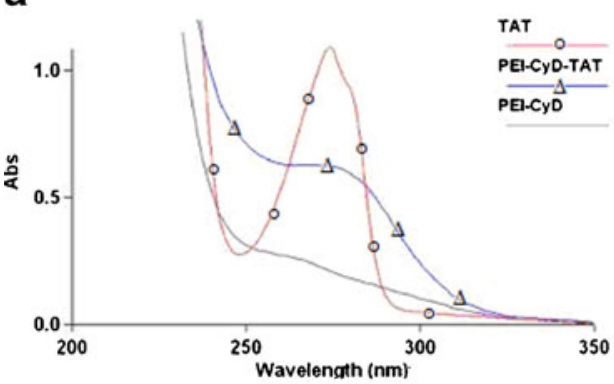

C

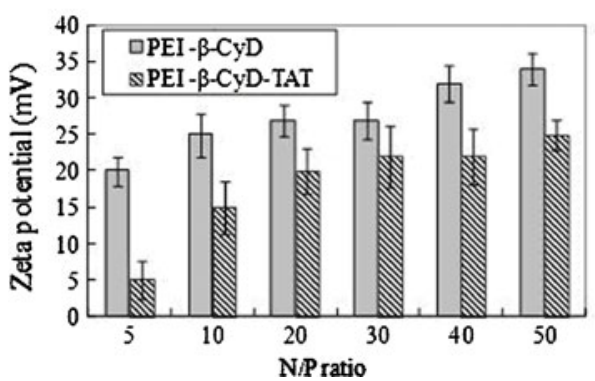

b

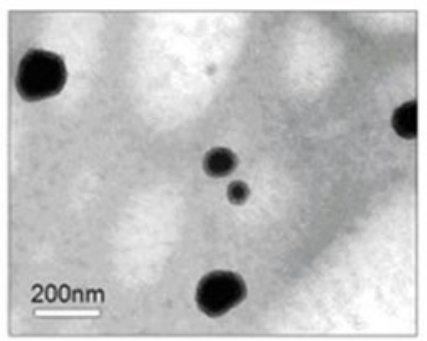

d

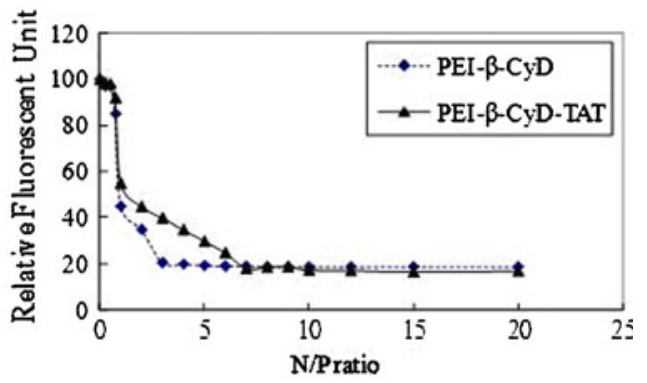

U87, U138, and 293T reached 50-80\%, while in Cho and HepG2, 34-40\% was reached. Importantly, we observed good transfectability of the polymer in PMSCs. According to Fig. 4 a, TAT-PEI- $\beta$-CyD not only has transfection efficiency (as determined by the percentage of cells exhibiting green fluorescence) around twice that of PEI- $\beta$ CyD after 48 and $96 \mathrm{~h}$ of post-transfection incubation, but also achieved more sustained transgene expression as compared to PEI- $\beta$-CyD. With immunophenotyping, similar expression profiles (including positivity for CD147 and CD90, but negativity for CD34, CD38, CD45 and HLADR) in the PMSCs before and after transfection were observed (data not shown). This demonstrated the maintenance of multipotency of PMSCs before and after TAT-PEIb-CyD-mediated transfection.

In the MTT assay performed on PMSCs, the cytotoxicity of TAT-PEI- $\beta-\mathrm{CyD}$ was found to be dose dependent. At a concentration up to $45 \mathrm{nM}$ of TAT-PEI- $\beta$-CyD, no statistically significant cytotoxicity was observed in PMSCs (Fig. 4b). Such low cytotoxicity is comparable to that of unmodified low molecular weight PEI and PEI- $\beta$-CyD as previously reported [25].

\section{Discussion}

Cyclodextrins (CyDs) are cyclic $(\alpha-1,4)$-linked oligosaccharides of $\alpha$-D-glucopyranose. They contain hydrophobic central cavities and hydrophilic outer surfaces. Common types of CyDs include $\alpha$-, $\beta$-, and $\gamma$-CyDs. They consist of six, seven and eight D-glucopyranose units, respectively. Due to their low toxicity, lack of immunogenicity, and ability to form inclusion complexes with a variety of guest molecules in solution and in solid state, CyDs have been extensively used as carriers to improve the solubility, stability, and bioavailability of chemical drugs [22]. Davis and colleagues modified the $\mathrm{CyD}$ structurally to make it possessing amine groups, granting it potential of being served as part of the backbone of other linear polymers [20]. Their polymer, CALAA-01, was finally developed as an experimental therapeutic that provides targeted delivery of synthetic siRNA in humans [21]. Numerous other CyDcontaining polymeric gene vectors have now been developed $[34,35]$. The majority of them are CyD dependent polymers with a polycation skeleton [22]. These polymers generally displayed improved transfection efficiency and lower toxicities when compared to their non-modified counterparts. Similar improvements in terms of transfection efficiency were also demonstrated in viral vectors upon CyD conjugation [36-38]. The mechanism underlying such an improvement is not clear. It is possible that CyDs can complex with phospholipids and cholesterols, thereby

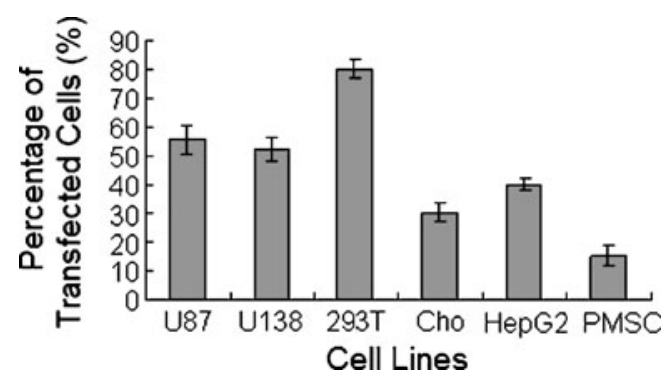

Fig. 3 The transfection efficacy of TAT-PEI- $\beta-C y D$ in various cell lines $(\mathrm{N} / \mathrm{P}=20,4.5-\mathrm{h}$ transfection and $48 \mathrm{~h}$ post-transfection incubation) 
a

(i)
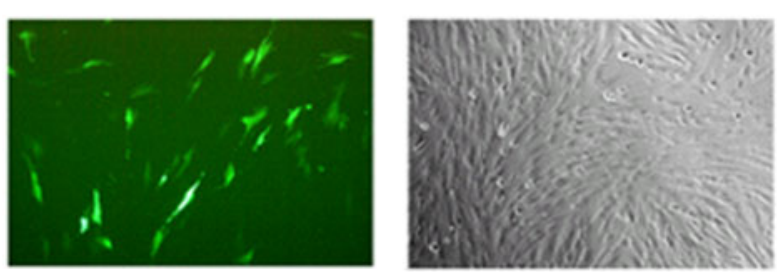

(ii)
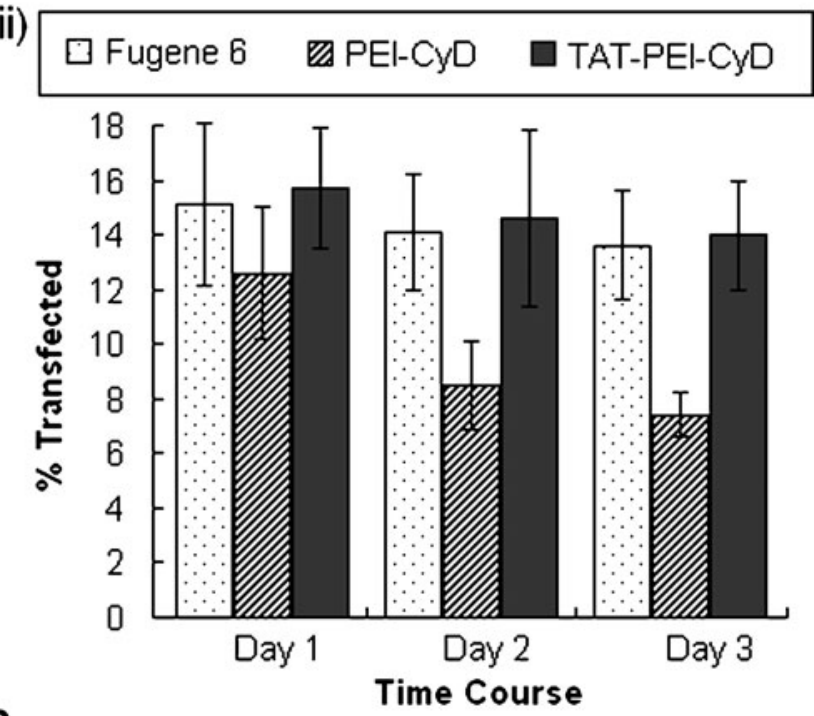

b

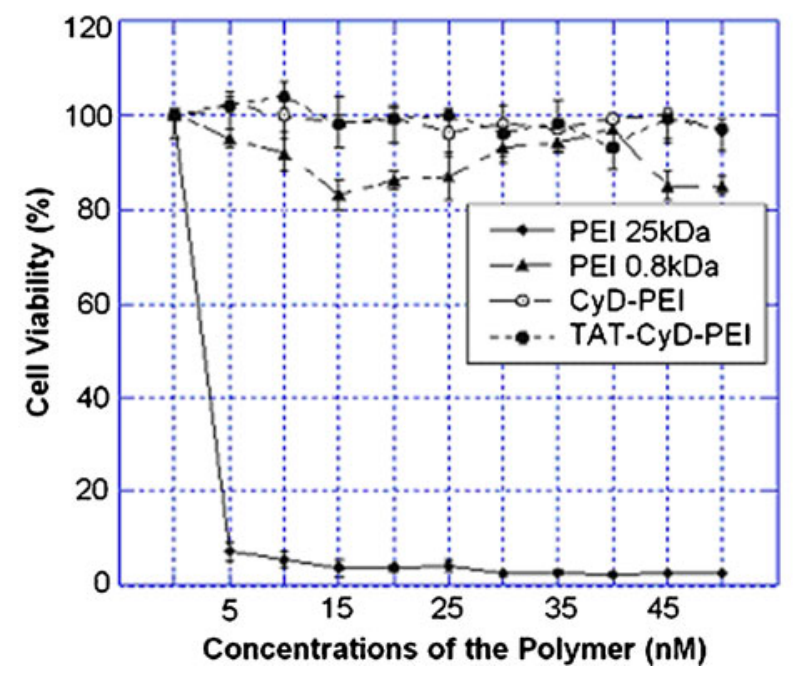

Fig. 4 a (i) Representative fluorescence and phase contrast micrographs of PMSCs captured $96 \mathrm{~h}$ after EGFP transfection (at N/P=20) mediated by TAT-PEI- $\beta$-CyD/pEGFP in the absence of $10 \%$ FBS. (ii) Time course study of transfection efficiency of TAT-PEI- $\beta-\mathrm{CyD} /$ pEGFP and PEI- $\beta$-CyD/pEGFP on PMSCs. b MTT assay in PMSCs. Cells were treated with PEI $25 \mathrm{kDa}$, PEI $0.8 \mathrm{kDa}$, PEI- $\beta$-CyD and TAT-PEI- $\beta$-CyD, respectively

disrupting biological membranes and assisting cellular uptake and/or intracellular trafficking of DNA.

Stem cells are difficult to transfect. Developing an efficient and non-toxic vector for pDNA transfer to stem cells would be of technical and practical importance. In our study human mesenchymal stem cells (MSCs) were used because their extraction raises less ethical concerns as compared to that of embryonic stem (ES) cells [39]. Further, because of their high proliferation potential and their abilities to differentiate into multiple lineages as well as to engraft onto numerous organs [32, 39, 40], MSCs have long been investigated as a therapeutic tool for biomedical applications, ranging from enhancement of angiogenesis in ischemic limbs [41] to tissue regeneration [42]. Their therapeutic appeal has been further promoted by recent reports which suggested that MSCs could potentially be used as "off-the-shelf" cells due to their immunotolerance properties [43]. The therapeutic efficacy of MSCs rely on their homing ability and their capacity to synthesize and secret the therapeutic proteins [10, 41, 44]. The development of a viable NA carrier for MSCs would be potentially of clinical importance.

Our backbone polymer, PEI- $\beta-\mathrm{CyD}$, is a safe and efficient polyplex-forming agent for both in vitro and in vivo pDNA transfection. It has previously been successfully conjugated with folic acid and demonstrated good transfection efficiency in cancer cells [45]. Here, we incorporated the PEI- $\beta$-CyD copolymer with the TAT peptide and tested its efficacy as a polymeric vector for pDNA delivery to stem cells. The PTD of the HIV-1 the TAT peptide could promote the cellular uptake of fusion proteins and other covalently linked small molecules into the cytoplasm [26, 27]. A 13-amino acid peptide (YGRKKRRQRRRPC derived from $\mathrm{TAT}_{(47-57)}$ with a $\mathrm{C}$ residue added to the $\mathrm{C}$-terminal to facilitate conjugation) was conjugated to the PEI- $\beta$-CyD polymer to produce TATPEI- $\beta$-CyD. The structure of the TAT-PEI- $\beta$-CyD was characterized by UV spectrophotometry (Fig. 2a). TAT exhibited an absorption peak at $285 \mathrm{~nm}$ due to the aromatic ring on its tyrosine residue. The presence of this peak in the spectrum of TAT-PEI- $\beta$-CyD but not PEI- $\beta$-CyD suggested the successful conjugation of TAT to PEI- $\beta$-CyD. Such an observation was further confirmed by the ${ }^{1} \mathrm{H}$ NMR spectrum of TAT-PEI- $\beta$-CyD which exhibited characteristic peaks for PEI $\left(\delta 2.8-3.2 \mathrm{ppm},-\mathrm{CH}_{2} \mathrm{CH}_{2} \mathrm{~N}-\right.$ protons of PEI), CyD ( $\delta 5.2 \mathrm{ppm}, \mathrm{H}_{1}$ of $\beta-\mathrm{CyD}, \delta 3.8-4.0 \mathrm{ppm}, \mathrm{H}_{3}$, $\mathrm{H}_{5}$, and $\mathrm{H}_{6}$ of $\beta$-CyD, $\delta 3.4-3.6 \mathrm{ppm}, \mathrm{H}_{2}$ and $\mathrm{H}_{4}$ of $\beta-$ $\mathrm{CyD})$ and TAT ( $\delta 1.6-1.9 \mathrm{ppm},-\mathrm{CH}_{2}-$ protons of TAT, $\delta$ 6.8-7.2 ppm, aromatic protons of TAT; Supplementary Data 1). Though it may be argued that similar UV and NMR spectra as those from Fig. 2a and Supplementary Data 1 could also be obtained by physical mixtures of TAT and the copolymer PEI- $\beta$-CyD; however, this possibility is minimal because unreacted TAT is expected to be removed completely by dialysis with dialysis tubing (molecular weight cut-off $=12 \mathrm{kDa}$ ) against water. The TAT peptide that remains is expected to have been attached covalently to PEI- $\beta$-CyD. Despite this, in case further confirmation of the covalent insertion of the TAT peptide on PEI- $\beta$-CyD is 
required for future research, employment of more sophisticated approaches such as mass spectroscopy for further characterization may be helpful.

As judged by the EGFP transfection assay, we observed that TAT-PEI- $\beta$-CyD has much higher transfection efficiency in PMSCs after 48 and $96 \mathrm{~h}$ of posttransfection incubation (Fig. 4a). This may pertain to the facilitation of cellular uptake of the pDNA polyplexes after the incorporation of the TAT peptide into the polymeric vector. Further, low cytotoxicity is an important criterion for a successful gene delivery system. Based on the MTT assay, we have recognized that TAT-PEI- $\beta$-CyD was non-toxic at its working concentrations (at an N/P ratio of 20) on PMSCs, on which over $80 \%$ of cell viability was maintained (Fig. 4b).

For future research, various polymeric modifiers can be applied to promote the transfection efficiency of the polymer towards PMSCs. The compositional ratio of PEI, $\beta-\mathrm{CyD}$ and TAT is also worth further optimization to finetune the structure of the polymer to the best possible transfection capacity. Here, it is worth noting that different types of stem cells might react differently towards TAT-PEI$\beta$-CyD-mediated transfection, causing the resultant efficacy to be varied. To confirm the actual applicability of the polymer in individual types of stem cells, specific in vitro studies are required. In addition, earlier studies recognized that different states (such as cell cycle states) of stem cells may restrict or alter the expression efficiency of the transgene delivered by cationic lipids [46]. However, how those factors could associate with the efficiency of polymeric stem cell transfection (especially those mediated by TAT-PEI- $\beta$-CyD) was ill-defined. Clarification of this issue could help to optimize the working conditions for polymer-mediated stem cell transfection, and to improve the efficiency thereof. Such information would be valuable to future research on stem cell therapy ex vivo, in vivo or even clinically.

\section{Conclusions}

An efficient yet non-cytotoxic vector is a sine qua non in NA therapy. At present, numerous NA carriers for cancer cells have been developed, yet efficient polymeric vectors for NA delivery into stem cells are heavily lacking. In fact, stem cells have presented themselves as being difficult to be transfected. This is also one of the biggest technical challenges in NA delivery research to date. This study demonstrates the feasibility of using TAT-PEI- $\beta$-CyD for the efficient transfer of pDNA into PMSCs while preserving multipotency and achieving high cell viability. It is anticipated that this polymer can be further developed into a non-viral NA delivery cargo for stem cells.
Open Access This article is distributed under the terms of the Creative Commons Attribution Noncommercial License which permits any noncommercial use, distribution, and reproduction in any medium, provided the original author(s) and source are credited.

\section{References}

1. De Sousa, P. A., Galea, G., Turner, M. (2006). The road to providing human embryo stem cells for therapeutic use: the UK experience. Reproduction, 132, 681-689.

2. Sell, S. (2006). Potential gene therapy strategies for cancer stem cells. Current Gene Therapy, 6, 579-591.

3. Lai, W. F. (2011). Delivery of therapeutics: current status and its relevance to regenerative innovations. Recent Patents on Nanomedicine, 1, 7-18.

4. Davila, J. C., Cezar, G. G., Thiede, M., Strom, S., Miki, T., Trosko, J. (2004). Use and application of stem cells in toxicology. Toxicological Sciences, 79, 214-223.

5. Gesslbauer, B., Krenn, E., Zenzmaier, C., Preisegger, K. H., Kungl, A. J. (2006). Lessons from the stem cell proteome. Current Stem Cell Research \& Therapy, 1, 395-409.

6. Hashino, S., Kobayashi, S., Takahata, M., Onozawa, M., Nakagawa, M., Kawamura, T., et al. (2008). Graft-versus-tumor effect after reduced-intensity allogeneic hematopoietic stem cell transplantation in a patient with advanced colon cancer. International Journal of Clinical Oncology, 13, 176-180.

7. Nagai, T., Shiojima, I., Matsuura, K., Komuro, I. (2005). Promotion of cardiac regeneration by cardiac stem cells. Circulation Research, 97, 615-617.

8. Morris, K. V., \& Rossi, J. J. (2006). Lentivirus-mediated RNA interference therapy for human immunodeficiency virus type 1 infection. Human Gene Therapy, 17, 479-486.

9. Check, E. (2003). Cancer risk prompts US to curb gene therapy. Nature, $422,7$.

10. Ferreira, E., Potier, E., Logeart-Avramoglou, D., SalomskaiteDavalgiene, S., Mir, L. M., Petite, H. (2008). Optimization of a gene electrotransfer method for mesenchymal stem cell transfection. Gene Therapy, 15, 537-544.

11. Kolodka, T. M., Garlick, J. A., Taichman, L. B. (1998). Evidence for keratinocyte stem cells in vitro: long term engraftment and persistence of transgene expression from retrovirus-transduced keratinocytes. Proc Natl Acad Sci USA, 95, 4356-4361.

12. Vassalli, G., Bueler, H., Dudler, J., von Segesser, L. K., Kappenberger, L. (2003). Adeno-associated virus (AAV) vectors achieve prolonged transgene expression in mouse myocardium and arteries in vivo: a comparative study with adenovirus vectors. International Journal of Cardiology, 90, 229-238.

13. Marwick, C. (2003). FDA halts gene therapy trials after leukaemia case in France. $B M J, 326,181$.

14. Park, T. G., Jeong, J. H., Kim, S. W. (2006). Current status of polymeric gene delivery systems. Advanced Drug Delivery Reviews, 58, 467-486.

15. Mintzer, M. A., \& Simanek, E. E. (2009). Nonviral vectors for gene delivery. Chemistry Review, 109, 259-302.

16. Lai, W. F., \& Lin, M. C. (2009). Nucleic acid delivery with chitosan and its derivatives. Journal of Controlled Release, 134, $158-168$

17. Lai, W. F., \& Lin, M. C. (2010). Chemical derivatization of chitosan for plasmid DNA delivery: present and future. In S. K. Kim (Ed.), Chitin, chitosan and their derivatives: biological activities and industrial applications (pp. 69-82). Florida: CRC.

18. Lai, W. F. (2011). In vivo nucleic acid delivery with PEI and its derivatives: current status and perspectives. Expert Review of Medical Devices, 8, 173-185. 
19. Ortiz Mellet, C., Garcia Fernandez, J. M., Benito, J. M. (2011). Cyclodextrin-based gene delivery systems. Chemical Society Reviews, 40, 1586-1608.

20. Gonzalez, H., Hwang, S. J., \& Davis, M. E. (1999). New class of polymers for the delivery of macromolecular therapeutics. Bioconjugate Chemistry, 10, 1068-1074.

21. Davis, M. E. (2009). The first targeted delivery of siRNA in humans via a self-assembling, cyclodextrin polymer-based nanoparticle: from concept to clinic. Molecular Pharmaceutics, 6, 659-668.

22. Davis, M. E., \& Brewster, M. E. (2004). Cyclodextrin-based pharmaceutics: past, present and future. Nature Reviews. Drug Discovery, 3, 1023-1035.

23. Lai, L. H., Jiang, Q. Y., Chen, D., Hu, Y. P., Yu, H., Wang, Q. Q., et al. (2009). Peptide TAT modified polyethylenimine-betacyclodextrin for gene delivery. Zhejiang Da Xиe Xиe Bao. Yi Xue Ban, 38, 15-23.

24. Li, J., \& Loh, X. J. (2008). Cyclodextrin-based supramolecular architectures: syntheses, structures, and applications for drug and gene delivery. Advanced Drug Delivery Reviews, 60, 1000-1017.

25. Tang, G. P., Guo, H. Y., Alexis, F., Wang, X., Zeng, S., Lim, T. M., et al. (2006). Low molecular weight polyethylenimines linked by beta-cyclodextrin for gene transfer into the nervous system. The Journal of Gene Medicine, 8, 736-744.

26. Eguchi, A., Akuta, T., Okuyama, H., Senda, T., Yokoi, H., Inokuchi, H., et al. (2001). Protein transduction domain of HIV1 Tat protein promotes efficient delivery of DNA into mammalian cells. Journal of Biological Chemistry, 276, 26204-26210.

27. Snyder, E. L., \& Dowdy, S. F. (2004). Cell penetrating peptides in drug delivery. Pharmaceutical Research, 21, 389-393.

28. Lai, W. F., \& Lin, M. C. M. (2010). Synthesis and properties of chitosan-PEI graft copolymers as vectors for nucleic acid delivery. Journal of Materials Science and Engineering, 4, 34-40.

29. In 't Anker, P. S., Scherjon, S. A., van der Keur Kleijburg, C., de Groot-Swings, G. M., Claas, F. H., Fibbe, W. E., et al. (2004). Isolation of mesenchymal stem cells of fetal or maternal origin from human placenta. Stem Cells, 22, 1338-1345.

30. Lu, L. L., Liu, Y. J., Yang, S. G., Zhao, Q. J., Wang, X., Gong, W., et al. (2006). Isolation and characterization of human umbilical cord mesenchymal stem cells with hematopoiesis-supportive function and other potentials. Haematologica, 91, 1017-1026.

31. Chen, C. P., Liu, S. H., Huang, J. P., Aplin, J. D., Wu, Y. H., Chen, P. C., et al. (2009). Engraftment potential of human placentaderived mesenchymal stem cells after in utero transplantation in rats. Human Reproduction, 24, 154-165.

32. Pittenger, M. F., Mackay, A. M., Beck, S. C., Jaiswal, R. K., Douglas, R., Mosca, J. D., et al. (1999). Multilineage potential of adult human mesenchymal stem cells. Science, 284, 143-147.

33. Chang, C. M., Kao, C. L., Chang, Y. L., Yang, M. J., Chen, Y. C., Sung, B. L., Tsai, T. H., Chao, K. C., Chiou, S. H., Ku, H. H. (2007). Placenta-derived multipotent stem cells induced to differentiate into insulin-positive cells. Biochemical and Biophysical Research Communications, 357, 414-420.

34. Pun, S. H., Bellocq, N. C., Liu, A. J., Jensen, G., Machemer, T., Quijano, E., et al. (2004). Cyclodextrin-modified polyethylenimine polymers for gene delivery. Bioconjugate Chemistry, 15, 831-840.

35. Forrest, M. L., Gabrielson, N., Pack, D. W. (2005). Cyclodextrinpolyethylenimine conjugates for targeted in vitro gene delivery. Biotechnology and Bioengineering, 89, 416-423.

36. Arima, H., Kihara, F., Hirayama, F., Uekama, K. (2001). Enhancement of gene expression by polyamidoamine dendrimer conjugates with alpha-, beta-, and gamma-cyclodextrins. Bioconjugate Chemistry, 12, 476-484.

37. Croyle, M. A., Roessler, B. J., Hsu, C. P., Sun, R., Amidon, G. L. (1998). Beta cyclodextrins enhance adenoviral-mediated gene delivery to the intestine. Pharmaceutical Research, 15, 1348-1355.

38. Lawrencia, C., Mahendran, R., Esuvaranathan, K. (2001). Transfection of urothelial cells using methyl-beta-cyclodextrin solubilized cholesterol and Dotap. Gene Therapy, 8, 760-768.

39. Parolini, O., Alviano, F., Bagnara, G. P., Bilic, G., Buhring, H. J., Evangelista, M., et al. (2008). Concise review: isolation and characterization of cells from human term placenta: outcome of the first international Workshop on Placenta Derived Stem Cells. Stem Cells, 26, 300-311.

40. Murphy, J. M., Fink, D. J., Hunziker, E. B., Barry, F. P. (2003). Stem cell therapy in a caprine model of osteoarthritis. Arthritis and Rheumatism, 48, 3464-3474.

41. Tang, Y. L., Zhao, Q., Zhang, Y. C., Cheng, L. L., Liu, M. Y., Shi, J. H., et al. (2004). Autologous mesenchymal stem cell transplantation induce VEGF and neovascularization in ischemic myocardium. Regulatory Peptides, 117, 3-10.

42. Petite, H., Viateau, V., Bensaid, W., Meunier, A., de Pollak, C., Bourguignon, M., et al. (2000). Tissue-engineered bone regeneration. Nature Biotechnology, 18, 959-963.

43. Jorgensen, C., Djouad, F., Apparailly, F., Noel, D. (2003). Engineering mesenchymal stem cells for immunotherapy. Gene Therapy, 10, 928-931.

44. Meinel, L., Hofmann, S., Betz, O., Fajardo, R., Merkle, H. P., Langer, R., et al. (2006). Osteogenesis by human mesenchymal stem cells cultured on silk biomaterials: comparison of adenovirus mediated gene transfer and protein delivery of BMP-2. Biomaterials, 27, 4993-5002.

45. Yao, H., Ng, S. S., Tucker, W. O., Tsang, Y. K. T., Man, K., Wang, X. M., et al. (2009). The gene transfection efficiency of a folate-PEI600-cyclodextrin nanopolymer. Biomaterials, 30, 5793-5803.

46. Zhang, P., Zhang, H., Hu, S. S., Chen, L. G., Wei, Y. J. (2005). Plasmid transfection of rat bone marrow mesenchymal stem cells by cationic lipid for gene-modified cell transplantation therapy. Zhongguo Yi Xue Ke Xue Yuan Xue Bao, 27, 504-508. 